DOI 10.15393/j9.art.2019.5921

УДК 398.21

Анастасия Сергеевна Лызлова

(Петрозаводск, Российская Федерачия)

alyzlova@illh.ru

\title{
Сказки о трех царствах (медном, серебряном и золотом) в лубочной питературе и фольклорной традиции
}

Аннотация. Статья посвящена популярному в русской устной фольклорной традиции сказочному сюжетному типу о трех царствах (золотом, серебряном и медном), известному в двух версиях: в одной из них царства располагаются под землей, а в другой находятся на горе. Появление второй версии связано с самой первой русской сказкой, опубликованной в 1782 г. Она называется «Сказка о золотой горе, или Чудные приключения Идана, восточного царевича» и наполнена специфическим восточным колоритом. Позднее текст был подвергнут русификации и печатался в различных лубочных изданиях, выходивших большими тиражами на протяжении почти 150 лет (конец XVIII - начало XX в.). Книжная сказка продолжила свое бытование в устной традиции: ее варианты записывались в различных уголках России и представлены во многих сборниках русских народных сказок, опубликованных в последней четверти XIX в., в первой половине XX в. и даже в начале XXI в. В этих текстах сохраняются отдельные детали (похищение матери героя, наличие четырех локусов, имя противника, превращение царств в яйцо и другие предметы), связанные именно с лубочными первоисточниками, которые не всегда легко узнаваемы, поскольку утрачиваются или трансформируются в процессе длительного существования устной сказочной традиции.

Ключевые слова: русская сказка, лубочная литература, сюжетный тип, версия, три царства, золотое царство, серебряное царство, медное царство

$\mathrm{K}$

онец XVIII столетия (1780-е гг.) ознаменован появлением первых публикаций сказок в России. Издание подобных текстов сказочного содержания, которые принято называть лубочными, занимающими промежуточное положение между фольклором и литературой, продолжалось вплоть до 1918 г; в их основе лежат как русские народные сказки, так и переводные повести и романы. Данное явление российской народной культуры всегда привлекало внимание исследователей, имеется и обобщающий труд К. Е. Кореповой «Русская лубочная сказка», в котором подробно рассмотрена история изучения 
этого жанра, охарактеризованы его специфические особенности, проанализированы отдельные сюжеты [Корепова, 1999, 2012].

Многие лубочные тексты сказочного характера оказали значительное воздействие на устную традицию: они были усвоены носителями фольклора и вошли в их репертуар. К числу подобных сюжетов относится тип, зафиксированный в указателе под номером 301A, В Три подземных ияарства; его краткое содержание передается в указателе следующим образом: «...герои идут искать исчезнувшую царевну; поочередно варят обед; старичок с ноготок калечит братьев или спутников силача, но терпит поражение в схватке с ним; тот по следам старичка опускается под землю или (реже) поднимается на гору, освобождает трех царевен и, несмотря на предательство братьев (спутников), не пожелавших вытащить его обратно, возвращается наверх (на гигантской птице); приходит на свадьбу царевны и мнимого ее спасителя; женится на ней» ${ }^{1}$ По данным А. В. Козьмина, указанный сюжетный тип является самым популярным в русской сказочной традиции [Козьмин: 158-159]. Как отмечают Л. Г. Бараг и Н. В. Новиков, этот «всемирно распространенный сюжет представлен в восточнославянском фольклорном материале большим, чем какой-либо другой, количеством записей. Русских вариантов 144 (из них 12 в сборнике Афанасьева), украинских - 58, белорусских - 32. <..> Старейшей зафиксированной версией является рассказ греческого писателя I в. н. э. Конона о пастухе, который был покинут товарищами в подземной пещере и прилетел оттуда на гигантском коршуне. Сказка типа $301-$ “Пегий бычок” (или “Беломордый бычок”) вошла в древний индийский сборник “Двадцать пять рассказов Веталы” и соответствующие ему тибетский и монголо-ойратский сборники “Игра Веталы с человеком" и “Волшебный мертвец". Мотивы сюжета известны по “Тысяче и одной ночи”» [Бараг, Новиков: 470-471]. В. Н. Топоров видел возможным существование индо-иранских параллелей: «...русская сказка типа 301 из всех пока известных версий этого сюжета в целом, несомненно, ближе всего к версии Фирдоуси в “Шах-наме”» [Топоров, 1995: 181]. 
Самой первой русской публикацией, относящейся к указанному сюжетному типу, является «Сказка о золотой горе, или Чудные приключения Идана, восточного царевича», анонимно вышедшая в 1782 г. в Петербурге2

Названная книга появилась ранее всех основных сказочных сборников конца XVIII в. («Лекарство от задумчивости и бессонницы, или Настоящие русские сказки», СПб., 1786; «Дедушкины прогулки, или Продолжение настоящих русских сказок», СПб., 1786; «Сказки русские, содержащие в себе 10 различных сказок. Собраны и изданы Петром Тимофеевым», M., 1787; «Старая погудка на новый лад», ч. 1-3, М., 1794-1795) и еще до окончания предпринятого В. Левшиным издания «Русских сказок, содержащих древнейшие повествования о славных богатырях...», ч. 1-10, М., 1780-1783. Как отмечает К. Е. Корепова, она «лежит у самых истоков русской лубочной сказки, но в ней уже определились характерные черты нового жанра, возникшего на путях сближения фольклора и литературы» [Корепова, 1991: 5].

В произведении сообщается о том, что у царя было три сына и красавица жена. Однажды во время прогулки ее похитил Вихрь. Сыновья по очереди отправляются на поиски матери. По пути они оказываются у своего дяди, снабжающего их клубком, указавшим путь к высокой золотой горе. На гору поднимается младший брат, используя для этого железные когти, надеваемые на руки и на ноги. На горе он встречается с царевнами медного, серебряного и золотого государств, а затем со своей матерью. Герой убивает Вихря и освобождает пленниц. Из-за братьев, перерезавших полотна, по которым осуществлялся спуск с горы, он остается в одиночестве. Возвращается оттуда благодаря волшебному духу. В своем царстве герой нанимается на работу к башмачнику. С помощью духа он выполняет три трудных задачи (сшить 12 дюжин башмаков, затем 12 дюжин пар платьев и, наконец, построить золотое государство, а от него до самого царского дворца золотой мост, покрытый зеленым бархатом). В результате этого царевна золотого государства узнает о его возвращении. Далее следует свадьба: три брата женятся на трех царевнах. 
Сюжетом сказки является посещение героем трех царств (медного, серебряного и золотого), осложненное поисками его похищенной матери. Расположение царств в данном тексте связано не с понижением уровня иного мира относительно мира этого, как в большинстве восточнославянских сказок, принадлежащих к рассматриваемому сюжетному типу, а с его повышением: эти самые царства находятся не под землей, а на горе.

Текст наполнен различными «восточными» элементами, что ощущается уже в самом названии, где герой обозначается как Идан, восточный царевич. Необычными именами наделены и другие персонажи: царя, который является правителем на Востоке, зовут Ислам, его жену Сумбуна, а двух старших сыновей Фигар и Мигул.

Особый «восточный» колорит заметен в той части произведения, где речь идет о посещении героем трех царств. Первым на его пути оказывается медное, представленное в виде «палатки, сделанной из самого тонкого батиста, на коем изображено было шитое разноцветными шелками медное государство. Оная палатка укреплена была к кипарисным деревьям оранжевого цвету шелковыми снурками с жемчужными кистьми, а на верху палатки поставлен из самой чистой меди шар, изображающий то государство» $(2001,22)$. В роли охраны выступают «ужасной величины три льва»; Идану-царевичу удается пройти мимо них, наполнив пустые медные тазы водой, «усмотря вдали колодезь, в который на шелковой веревке опущен был медный ковш». Он попадает в палатку, где видит «на софе, обитой белым атласом с шелковую бахромою, сидящую царевну редкой красоты» $(2001,22)$. Медное царство представлено здесь в виде шатра, при описании которого упоминаются разнообразные ткани (батист, шелк, атлас), жемчуг, металлические предметы (медная посуда), мебель (софа), кисти и бахрома, а также кипарисы и львы. Все эти атрибуты можно расценивать как приметы Востока.

Покинув медное государство, Идан попадает в «другую палатку, из самого тонкого ширу сделанную, которую укрепляли привязанные к кедровым деревьям серебряные снурки, у коих кисти были изумрудные. На той палатке изображено 
было вышитое серебром серебряное государство, а на верху оной поставлен шар из самого чистого серебра» $(2001,23)$. Он опять же вынужден напоить животных (в данном случае трех тигров), добавив воду в три серебряных таза, используя серебряный ковш. После герой оказывается в палатке, где «представилась глазам его сидящая на софе, обитой голубым атласом с золотою бахромою, унизанною разноцветными яхонтами, гораздо превосходнее красотою первой, царевна» $(2001,23)$. Серебряное царство - это также шатер, при описании которого опять же упоминаются ткани (атлас, шир), драгоценные камни (изумруды, яхонты), более благородный металл (серебро) и созданная из него посуда; здесь фигурируют кедры и тигры.

Третьим на пути оказывается золотое государство, представленное в виде «палатки, из тончайшего камортку сделанной, на коей золотом вышито было золотое государство. Оная палатка укреплена была к лавровым деревьям золотыми снурками, у коих кисти были алмазные, а на палатке поставлен шар из чистейшего золота, который казался светящим, как солнце» $(2001,24)$. В качестве защиты здесь выступают двенадцать крокодилов, которых царевич усмиряет, добавив воды в золотые тазы, используя золотой ковш. Оказавшись внутри, он встречает «беспримерной красоты царевну, сидящую на софе, розовым атласом обитой, с бахромою, бурмицкими зернами унизанною» $(2001,25)$. При описании этого царства упоминаются ткани (атлас, каморто́к / камо́рток), мрамор, алмазы и бурмицкое зерно (т. е. жемчуг), еще более благородный металл (золото) и сделанная из него посуда, снова софа, бахрома и кисти; лавры и крокодилы.

Фигурирует здесь и четвертое царство, изображаемое в виде «наивеликолепнейшего дворца, из чистого янтаря сделанного», внутри которого «стены усыпаны были драгоценными каменьями»; в нем герой и увидел «на бриллиантовом троне сидящую в царской одежде мать свою» $(2001,26)$. Этот дворец превосходит предыдущие царства, он еще более роскошен.

$\mathrm{B}$ «Сказке о золотой горе» имеются подробные описания самих трех царств (медного, серебряного и золотого) и их соответствующих атрибутов; кроме того, появляется дополнительное, четвертое, 
описание царства, возникшее, по всей видимости, по воле автора текста.

Сказка наполнена различными «экзотическими» элементами (необычные имена персонажей, животные, растения, предметы быта). Изображаемые три царства и дворец, в котором пребывает мать героя, отличаются богатством и роскошью. Присутствие такого необычного «восточного» колорита способствовало тому, что, к примеру, Д. А. Ровинский отнес ее к числу «сказок, переведенных почти без переделок с западных оригиналов» [Ровинский, 2002: 120], но при этом не указал источник. На вопрос о том, «переводная ли данная сказка или народная, но ориентализированная», пытался ответить С. В. Савченко: «Мы также не решаемся решительно примкнуть к той или иной точке зрения, но считаем более вероятным второе предположение» [Савченко: 94]. По мнению К. Е. Кореповой, в этом произведении «за “восточными” именами (Идан, Мигул, Сумбуна и т. д.) и экзотическими персонажами, вроде тигров и крокодилов, легко узнавалась популярная в русском фольклоре сказка о трех царствах» [Корепова, 2001: 6]. В «Сказке о золотой горе» изображаемым событиям придана некоторая условная достоверность. Представленная в ней приближенность к реальной действительности, заключающаяся в использовании Востока в качестве места действия и употреблении различных "восточных» атрибутов, является одним из главных отличий книжной лубочной сказки от фольклорной. Другими характерными чертами выступают замысловатый стиль изложения, обилие второстепенных персонажей, которые не выполняют в дальнейшем никаких действий, и различных подробных описаний.

«Сказка о золотой горе» дважды переиздавалась: в 1790 г. в Москве и в 1831 г. в Петербурге; в 1793 г. была также опубликована в СанктПетербурге в составе неболышого сборника «Исторические сказки». Она неоднократно перепечатывалась в лубочных картинках, где приобрела сокращенный вид и русифицированный характер благодаря замене имен: вместо Фигара, Мигула и Идана здесь фигурируют Василий-царевич, Федор-царевич и Иван-царевич. В собрании Д. А. Ровинского «Русские народные картинки» под № 47 зафиксирована «Сказка о золотом, серебряном и медном государствах», 
а под № 48 «Сказка о золотой горе». В комментарии составителя отмечается:

«Это одна и та же сказка, изданная под разными названиями. Единственные экземпляры той и другой находятся в публичной библиотеке (из собрания Даля). Сказка о “золотом, серебряном и медном государствах" напечатана в начале XIX века; сказка же о “золотой горе" позднее, в 1820-30 годах. Обе гравированы на меди, трехлистовые, в двенадцати картинках каждая. Картинки той и другой сделаны с одного образца, содержание их ${ }^{3}$ следующее:

1) Иван-царевич просится у отца своего в путь.

2) Приезжает к королю, своему дяде.

3) Взбирается на гору.

4) Беседует с царевной медного царства.

5) Беседует с царевною серебряного царства.

6) Беседует с царевною золотого царства.

7) Находит свою мать.

8) Остается один на горе, обманутый братьями.

9) Какой-то "человек" перенес его в город отца его.

10) Изображение дворца.

11) Иван-царевич встречает отца и мать.

12) Раздает царевен братьям» [Ровинский, 1881: 182-183].

Помещенный у Д. А. Ровинского текст сказки, сопровождающий картинки, был перепечатан А. Н. Афанасьевым в «Примечаниях», с заменой в названии слова «государствах» на «царствах» (3, 224-226, № 559).

В составе сборника «Старая погудка на новый лад» (ч. 1-3, М., 1794-1795) опубликована «Сказка о Василие-королевиче» ${ }^{4}$, основой для создания которой также послужил текст из народных картинок, представляющий собой переработанный вариант «Сказки о золотой горе».

Три отмеченных текста практически полностью совпадают. Так, в них завязкой действия служит похищение жены царя во время прогулки по саду «в один день» / «в одно время», сопровождающееся вихрем: «вдруг поднявшись, вихорь унес супругу из глаз его» $(2001,19)$; «вдруг поднялся вихорь и унес царицу из глаз его» $(3,224)$; «вдруг поднялся великий вихорь и, схватя на воздух королеву, унес ее в неизвестное королевство» $(2003,268)$. 
На поиски матери отправляются сыновья. В определенный момент повествования они оказываются у подножия горы, подняться на которую удается младшему с помощью специальных средств: «попались ему весьма острые железные на руки и на ноги когти» $(2001,21)$, «помощью коих взошел он на самый верх горы» $(3,224-225)$, «вздев на себя» $(2003,270)$.

В восходящих к «Сказке о золотой горе» двух лубочных вариантах сохранены и «восточные» элементы, используемые при описании трех расположенных на горе царств: упоминаются медная, серебряная и золотая палатки, шары из соответствующих материалов, дорогие ткани (батист, флер), драгоценные камни (изумруды, алмазы), мебель (софа), животные (львы, тигры и крокодилы), растения (лавры, кедры).

В анализируемых текстах результатом посещения героем трех царств является освобождение девушек, сопровождающееся превращением каждого из локусов в яйцо: «царевна $<\ldots>$ в залог своей к нему верности отдала ему медное яйцо, которое развернув, показала ему скрытое в нем медное государство, коим она обладает» $(2001,22)$; «королевна, видя неустрашимость такого героя, благодарила его за оказанную услугу и подарила ему яйцо, сокрывающее в себе серебряное королевство» $(2003,270)$; «царевна <...> подарила ему золотое яйцо, содержащее в себе золотое государство» $(3,225)$. По словам В. Е. Добровольской, яйцо связано с представлениями о сотворении мира, а «сравнение яйца с царством или дворцом могло сформироваться в сказке и под влиянием загадок, где яйцо описывается как некий пространственный объект» [Добровольская: 107] .

Добравшись до матери, пребывающей в четвертом царстве, герой вступает в поединок с противником, которым в лубочной сказке, помещенной в собрание А. Н. Афанасьева, также оказывается Вихрь, а вот в тексте из второго сборника он заменяется более распространенным в фольклорной традиции образом змея. Схватка заканчивается смертью похитителя, который «с высоты устремился <...> вниз и ударился оземь, так что рассыпался на самые мелкие частицы» (2001, 27-28); «осердясь на царевича, поднялся на высоту, потом спустился на землю и рассыпался на мелкие части» $(3,225-226)$; «ударившись сам 
о сыру землю, рассыпался сам на мелкие части» $(2003,272)$. Одержавший победу сын сжигает эти остатки, зарывает пепел в землю или развеивает его по полю и становится обладателем волшебной палицы.

Возвращению спасителя с горы препятствуют братья, оставившие его на вершине в одиночестве, но он, появившись в своем мире через какое-то время с помощью духа из палицы, прощает их и распределяет жен: старшему назначается в супруги царевна из серебряного государства, среднему - из медного, самому герою - из золотого. Необычные имена героев «Сказки о золотой горе» (Фигар, Мигул и Идан) в поздних лубочных обработках заменяются на более привычные Василий, Федор и Иван. Что касается девушек, то в первой печатной сказке они безымянны, в двух других лубочных текстах царевну из медного царства зовут Земира, царевну из золотого царства - Пленира, а царевну из серебряного царства Елена $(3,226)$ или Улита $(2003,274)$.

«Сказка о золотой горе» и ее переработанные варианты, публиковавшиеся в народных лубочных картинках и один помещенный в сборнике «Старая погудка на новый лад», оказали большое влияние на устную традицию. Они обеспечили возникновение новой версии сюжетного типа 301A, В Три подземных изарства, в которой соответствующие дворцы (или царства) находятся на горе. Составители указателя 1979 года дали не совсем верное наименование данному сюжетному типу. Кстати, в указателе Н. П. Андреева он озаглавлен Три изарства: медное, серебряное и золотое, что более правильно ${ }^{6}$. В самом позднем из существующих на сегодняшний день указателе по системе Аарне, подготовленном Г.-Й. Утером в начале XXI в. (ATU), сюжетный тип под номером 301 называется The Three Stolen Princesses / Три похищенных принuессыl. В нем учитываются различные версии подобных сказок, распространенных по всему миру, в которых герой (или братья-герои) освобождают трех девушек / похищенных королевских дочерей из подземного или верхнего миров.

Влияние опубликованных в XVIII столетии сказок заметно уже в первых научных сборниках, составленных А. Н. Афанасьевым («Народные русские сказки», 1855-1863 гг.) и И. А. Худяковым 
Сказки о трех царствах (медном, серебряном и золотом)...

(«Великорусские сказки», 1860-1862 гг.). К лубочным сказкам восходят следующие тексты, представленные в устной традиции:

\begin{tabular}{|c|c|c|c|}
\hline № & Название & Место записи & Время \\
\hline 1 & $\begin{array}{l}\text { «Три царства - } \\
\text { медное, серебряное } \\
\text { и золотое» }(1,189- \\
\text { 195, № 129) }\end{array}$ & Воронежская губ. & - \\
\hline 2 & $\begin{array}{c}-/ /-(1,195- \\
199 \text {, № 130) }\end{array}$ & - & - \\
\hline 3 & $\begin{array}{l}\text { «Арикад-царе- } \\
\text { вич» }\end{array}$ & Рязанская губ. & 1861 г. \\
\hline 4 & $\begin{array}{l}\text { «Василий-царе- } \\
\text { вич» }\end{array}$ & Рязанская губ. & 1862 г. \\
\hline 5 & $\begin{array}{l}\text { «О Вороне } \\
\text { Вороне́виче, Вихре } \\
\text { Вихре́виче, силь- } \\
\text { ном, могучем } \\
\text { бога́тыре» }^{10}\end{array}$ & Томская губ. & 1905 г. \\
\hline 6 & $\begin{array}{l}\text { «Иан-короле- } \\
\text { вич» } 11\end{array}$ & Вологодская губ. & 1909 г. \\
\hline 7 & $\begin{array}{l}\text { «Иван-царевич } \\
\text { и Митрей-царе- } \\
\text { вич» }\end{array}$ & Вологодская губ. & 1909 г. \\
\hline 8 & $\begin{array}{l}\text { «Bexорь Bexope- } \\
\text { вич» }^{13}\end{array}$ & Архангельская губ. & 1921 г. \\
\hline 9 & $\begin{array}{l}\text { «Вихрево́е цар- } \\
\text { ство» }{ }^{14}\end{array}$ & Олонецкая губ. & 1926 г. \\
\hline 10 & $\begin{array}{l}\text { «Ворон Вороно- } \\
\text { вич» } 15\end{array}$ & Архангельская губ. & 1927 г. \\
\hline 11 & $\begin{array}{l}\text { «Сказка про 3о- } \\
\text { лотую гору» }\end{array}$ & Олонецкая губ. & 1926 г. \\
\hline 12 & 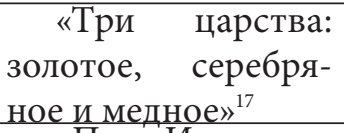 & Архангельская губ. & 1927 г. \\
\hline 13 & $\begin{array}{c}\text { "Про Ивана-ца- } \\
\text { ревича»" }\end{array}$ & Архангельская губ. & 1928 г. \\
\hline 14 & $\begin{array}{l}\text { «ро Ивана-ца- } \\
\text { ревича» }\end{array}$ & Новгородская обл. & 1972 г. \\
\hline
\end{tabular}

Приведенные сказки записаны преимущественно на Русском Севере в разное время: первые записи относятся к 1850- 
1860-м гг. и самому началу XX столетия, большая часть собрана в 1920-х гг., последняя известная нам сказка была сообщена в 1972 г. Все эти фольклорные варианты в большей или меньшей степени сохраняют черты, идущие от книги. Во многих из них герой отправляется на поиски пропавшей матери, а посещение трех царств является своего рода промежуточным эпизодом на пути к цели. Как правило, в сказках подчеркивается, что они непременно оказываются медным, серебряным и золотым. Подобное сочетание используется и в книжных источниках, упоминавшихся выше. Как отмечает К. Е. Корепова, рассмотревшая шесть из названных сказок, опубликованных в сборниках А. Н. Афанасьева, И. А. Худякова, братьев Соколовых и А. И. Никифорова, отдельные «варианты были непосредственным пересказом книжного текста, и потому сходство их так велико. В текстах, разделенных с первоисточником промежуточными вариантами, совпадений, конечно, меньше, в них исчезли какие-то эпизоды, введены новые. И все-таки протограф угадывается, хотя иногда с трудом. Выдают его сохранившиеся книжные детали, часто тоже уже трансформировавшиеся» [Корепова, 1991: 9]. Все это вполне применимо и к остальным имеющимся в нашем распоряжении сказкам.

В подавляющем числе текстов завязкой действия служит похищение царицы / королевы во время прогулки, осуществляемое Вихрем. В процессе длительного бытования устной сказочной традиции персонаж подвергся трансформациям: у Вихоря Вихоревича появляются девять голов ${ }^{20}$ или же он заменяется змеем ${ }^{21}$. В одном из вариантов сборника, подготовленного А. Н. Афанасьевым, сообщается, как «сотряслась беда немалая - утащил царицу нечистый дух» (1, 195, № 130), но в ходе повествования выясняется, что на самом деле похитителем оказывается Ворон Воронович. В записанной в 1905 г. в Барнаульском уезде Томской губ. (сейчас Алтайский край) сказке при обозначении соответствующего персонажа используются оба наименования: «Накатилась туча, и вылетает из тучи Ворон Вороне́вич-Вихорь Вихоре́вич, сильный, могучий бога́тырь. Ухватил ихню мать, стал поднимать кверху»22. В одном из текстов сборника «Сказки и предания Северного края» 
в качестве похитителя сестры героя выступает Ворон Воронович, Когот Коготович 23 . Эта сказка была записана почти в одно время (1926 и 1927 гг.) и на одной территории (Архангельская обл.), что и вариант, помещенный в сборнике А. И. Никифорова, где фигурирует «Кокот Кокотовиць Крёкот Крёкотовиць» ${ }^{24}$. Появление наименования может быть связано с оглушением согласных звуков в сочетании «Когот Коготович». В «Словаре малоупотребительных и областных слов», составленном В. Я. Проппом и представленном в сборнике А. Н. Афанасьева, «кокот»- «петух, кочет» ${ }^{25}$, а «кректать», согласно «Словарю русских народных говоров», - «издавать крик (о птицах)» ${ }^{26}$.

Почти во всех вариантах, представленных в устной традиции, граница между своим и чужим мирами изображается в виде горы, на которую можно подняться с помощью специальных приспособлений (когтей, цепи, лестницы). Лишь в единичном случае, возникшем, вероятно, под влиянием более распространенной версии, герой оказывается в подземельной яме $(1,196$, № 130). В одной из сказок на горе располагается «провалища, и вокруг провалища у́толка (от утолочь - утоптанная земля) велика» ${ }^{27}$. Попасть туда можно, используя «рели» $(1,196$, № 130) (т. е. столбы с перекладиной, качели, перила) или же ремни, сшитые из шкур животных ${ }^{28}$.

В текстах, за редким исключением, сохраняется связанное с книжными первоисточниками наличие четырех царств ${ }^{29}$, где пребывают девушки и похищенная мать (или - в единичных случаях - сестра) героя. Иногда и в устных вариантах подчеркивается роскошность четвертого локуса: это может быть жемчужное царство $\left(1,197\right.$, № 130), драгоценный ${ }^{30}$ или хрустальный ${ }^{31}$ дворец, «дом золотой и драгоценным каменьем высажен» ${ }^{32}$, «дом снаружи убран драгоценными камнями» ${ }^{33}$, дворец «в бриллиантах и самоцветных каменьях» (1, 191, № 129). В ряде сказок представлен также мотив сворачивания трех царств в яйцо, которое в процессе устного бытования заменяется другими эквивалентными атрибутами (яблоком, кольцом, клубком, шариком, шкатулкой, платком), служащими местами для вре́менного хранения локусов и последующего 
извлечения с целью выполнения героем каких-либо предсвадебных испытаний (см. об этом: [Лызлова: 145-146]).

Что касается появления образа самих трех царств, то, например, по словам В. Н. Топорова, «царство и дом в типе 301 находятся чаще всего в отношении свободного чередования или дублирования (отсюда - золотое царство или золотой дом, серебряное царство или серебряный дом, медное царство или медный дом, с одной стороны, и золотой дом в золотом царстве и т. д., с другой стороны)» [Топоров, 1967: 86]. В. Я. Пропп считал, что «эти три царства возникли как утроение тридесятого царства. При стремлении сказки все утраивать этому стремлению несомненно подвергся и данный мотив, и этим вызвано наличие вообще трех царств, но так как тридесятое царство золотое, то предыдущие сделаны серебряным и медным. Искать здесь каких-то связей с представлениями о железном, серебряном и золотом веке, вообще с циклом гесиодовских эр - напрасный труд. Здесь не удастся также обнаружить никаких связей с представлениями о металлах» [Пропп: 246]. Последнее заключение требует незначительной корректировки. В отдельных сказках сообщается, что не только сами царства сделаны из соответствующего металла, но и многие атрибуты в них тоже:

«Приходит <Иван-царевич> в серебряное царство и видит дворец лучше прежнего - весь серебряный; у ворот страшные змеи на серебряных цепях прикованы, а подле колодезь с серебряным корцом (ковшом. - А. Л.)» $(1,190$, № 129);

«...стоит дом медный и кругом ограда медная. У ворот стоит собака <...>, на медной цепи привязана» ${ }^{34}$.

Скорее всего, эти описания связаны опять же с книжными источниками. Примечательно, что в одном из фольклорных текстов соответствующая характеристика переносится на облик похитителей: три сестры героя оказываются женами трех братьев Воронов Вороновичей, Коготов Коготовичей, способных менять свой орнитоморфный облик на антропоморфный, у одного из них «медный нос, оловянный хвос», у второго «серебряный нос, чугунный хвос», у третьего «золотой нос и стальной хвос» ${ }^{35}$. Сама сказка относится к совершенно другому 
сюжетному типу, зафиксированному в СУС под номером 552A Животные-зятья.

Использование при характеристике царств эпитетов золотой, серебряный, медный заключает в себе определенный оценочный момент. Как отмечает М. К. Азадовский, «в сказке строго соблюдаются общеэпические законы: трехчленность (три сына, три дочери, три подвига, три противника, три задачи, три попытки добиться желаемого), причем трехчленность тесно связана с градацией; каждый противник сильнее предыдущего: змей о трех головах, о шести, о двенадцати; каждая задача трудней предыдущей, а каждое царство или дворец ценнее: царство медное, серебряное и золотое, и т. д.» [Азадовский: 25]. Именно поэтому самая лучшая девушка проживает в золотом царстве или доме, а не в медном или серебряном; и она становится в конечном итоге женой главного героя.

Итак, популярная сказка о трех царствах представлена в русской фольклорной традиции двумя версиями, появление одной из которых однозначно связано с лубочной литературой. Все рассмотренные источники включены составителями сюжетного указателя в тип СУС 301A, В Три подземных ияарства, хотя заметно отличаются от второй его версии, где как раз отражено нижнее (подземное) расположение локусов.

Книжный по происхождению текст, подвергнувшись фольклоризации, начал жить по законам устного народного творчества, получив достаточное количество вариантов, в которых - наряду с сохраняющимися лубочно-литературными чертами - появляются и другие детали, возникающие в процессе длительного бытования. 


\section{Примечания}

"Финансовое обеспечение исследования осуществлялось из средств федерального бюджета на выполнение государственного задания Карельского научного центра РАН (проект АААА-А18-118030190094-6).

1 СУС - Сравнительный указатель сюжетов. Восточнославянская сказка / сост. Л. Г. Бараг, И. П. Березовский, К. П. Кабашников, Н. В. Новиков. Л.: Наука, 1979. С. 106.

2 Сказка о золотой горе, или удивительные приключения Идана, восточного царевича (1782 г.) // Лекарство от задумчивости. Русская сказка в изданиях 80-х годов XVIII века / изд. подгот. К. Е. Корепова и Л. Г. Беликова. СПб.: Тропа Троянова, 2001. С. 19-38. Далее ссылки на это издание приводятся в тексте статьи с указанием года издания и страницы в круглых скобках.

3 Попутно отметим, что все двенадцать картинок приводятся в качестве иллюстраций в последнем переиздании сборника А. Н. Афанасьева, подготовленного Л. Г. Барагом и Н. В. Новиковым (см.: Народные русские сказки А. Н. Афанасьева: в 3 т. / изд. подгот. Л. Г. Бараг и Н. В. Новиков. М.: Наука, 1984. Т. 1. С. 180-186. Далее ссылки на это издание приводятся в тексте статьи с указанием тома и страницы в круглых скобках, в некоторых случаях указывается номер текста).

4 Сказка о Василие-королевиче // Старая погудка на новый лад. Русская сказка в изданиях конца XVIII века / изд. подгот. К. Е. Корепова и Л. Г. Беликова. СПб.: Тропа Троянова, 2003. С. 268-274. Далее ссылки на это издание приводятся в тексте статьи с указанием года издания и страницы в круглых скобках.

5 См. подробнее о связи яйца с представлениями о сотворении мира: [Лызлова: 143-146].

6 Андреев Н. П. Указатель сказочных сюжетов по системе Аарне. Л.: Изд-во госуд. рус. геогр. общ., 1929. С. 26.

7 Uther H.-J. The Types of International Folktales: A Classification and Bibliography. Pt. 1. Helsinki: Academia Scientiarum Fennica, 2004. P. 176.

8 Худяков И. А. Великорусские сказки. Великорусские загадки / изд. подгот. Е. А. Костюхин и Л. Г. Беликова. СПб.: Тропа Троянова, 2001. № 43. C. $149-159$.

9 Там же. С. 247-250 (№ 82).

10 Русские и инородческие сказки Енисейской и Томской губерний. Записки РГО 1906 года // Русские сказки и песни в Сибири. СПб.: Тропа Троянова, 2000. № 31. С. 444-448.

11 Сказки и песни Белозерского края. Сборник Б. и Ю. Соколовых: в 2 кн. СПб.: Тропа Троянова, 1999. Кн. 1. С. 380-385 (№ 79).

12 Там же. С. 616-627 (№ 153).

13 Озаровская О. Э. Пятиречие. СПб.: Тропа Троянова, 2000. С. 252-266 (№ 26).

14 Карнаухова И. В. Сказки и предания Северного края / подгот. текстов, вступ. ст., коммент. М. Н. Власовой. СПб.: Тропа Троянова, 2006. 
C. 54-58 (№ 14).

15 Там же. С. 247-253 (№ 124).

16 Неизданные материалы экспедиций на Русский Север 1926-1928 гг. СПб., 2011. № 1. С. 23-27.

17 Севернорусские сказки в записях А. И. Никифорова / изд. подгот. В. Я. Пропп. М.; Л.: Изд-во АН СССР, 1961. С. 179-185 (№ 79).

18 Там же. С. 329-340 (№ 131).

19 Традиционный фольклор Новгородской области. СПб.: Алетейя, 2001. С. 49-53 (№ 35).

20 Сказки и песни Белозерского края. С. 622 (№ 153).

21 Там же. С. 382 (№ 79).

22 Русские и инородческие сказки Енисейской и Томской губерний. С. 444 (№ 31).

23 Карнаухова И. В. Сказки и предания Северного края. С. 247-253 (№ 124).

24 Севернорусские сказки в записях А. И. Никифорова. С. 179-185 (№ 79).

25 Народные русские сказки А. Н. Афанасьева: в 3 т. / подгот. текста, предисл. и примеч. В. Я. Проппа. М.: Гослитиздат, 1957. Т. 2. С. 506.

26 Словарь русских народных говоров. Л.: Наука, 1979. Вып. 15. С. 209.

27 Русские и инородческие сказки Енисейской и Томской губерний. С. 444 (№ 31).

28 Там же.

29 Лишь в нескольких текстах фигурируют три царства, а не четыре: Сказки и песни Белозерского края. С. 381-382 (№ 79); С. 619-620 (№ 153); Карнаухова И. В. Сказки и предания Северного края. С. 56 (№ 14).

30 Неизданные материалы экспедиций... № 1. С. 25.

31 Худяков И. А. Великорусские сказки. С. 153 (№ 43).

32 Севернорусские сказки в записях А. И. Никифорова. С. 331 (№ 131).

33 Худяков И. А. Великорусские сказки. С. 248 (№ 82).

34 Севернорусские сказки в записях А. И. Никифорова. С. 330 (№ 131).

35 Русские народные сказки Пудожского края / изд. подгот. А. П. Разумова, Т. И. Сенькина. Петрозаводск: Карелия, 1982. С. 181-183 (№ 27).

\section{Список литературы}

1. Азадовский М. К. Русские сказочники // Азадовский М. К. Статьи о литературе и фольклоре. - М.; Л.: Гослитиздат, 1960. - С. 15-79.

2. [Бараг Л. Г., Новиков Н. В.] Примечания // Народные русские сказки А. Н. Афанасьева: в 3 т. / изд. подгот. Л. Г. Бараг и Н. В. Новиков. - М.: Наука, 1984. - Т. 1. - С. 432-505.

3. Добровольская В. Е. Предметные реалии русской волшебной сказки. М.: Государственный республиканский центр русского фольклора, 2009. - 224 c.

4. Козьмин А. В. Популярность сказочных сюжетов // Проблемы структурносемантических указателей. - М.: Изд-во РГГУ, 2006. - С. 156-166.

5. Корепова К. Е. Лубочные сказки о трех подземных царствах и их влияние 
на устную традицию // Фольклор народов РСФСР. - Уфа: Изд-во Башкирского ун-та, 1991. - С. 5-12.

6. Корепова К. Е. Русская пубочная сказка. - Нижний Новгород: КиТиздат, 1999. - 243 с.

7. Корепова К. Е. У самых истоков // Лекарство от задумчивости. Русская сказка в изданиях 80-х годов XVIII века. - СПб.: Тропа Троянова, 2001. - C. 5-16.

8. Корепова К. Е. Русская лубочная сказка. - М.: ФОРУМ, 2012. - 464 с., илл.

9. Лызлова А. С. Ab ovo: о семантике сказочного образа // Проблемы исторической поэтики. - 2016. - № 4. - С. 136-152 [Электронный pecypc]. - URL: http://poetica.pro/files/redaktor_pdf/1481891910.pdf (18.12.2018). DOI: 10.15393/j9.art.2016.3748

10. Пропп В. Я. Исторические корни волшебной сказки. - М.: Лабиринт, 2005. - 332 c.

11. [Ровинский Д.] Русские народные картинки: в 5 кн. Собрал и описал Д. Ровинский. Кн. 1. - СПб.: Типография Академии наук, 1881. - 509 с.

12. [Ровинский Д.] Русские народные картинки. Собрал и описал Д. Ровинский. - СПб.: Тропа Троянова, 2002. - 342 с., илл.

13. Савченко С. В. Русская народная сказка: История собирания и изучения. - Киев: Типография Императорского Университета св. Владимира, 1914. -543 c.

14. Топоров В. Н. К реконструкции мифа о мировом яйце (на материале русских сказок) // Труды по знаковым системам. - Тарту: Изд-во Тартуского ун-та, 1967. - Вып. 3. - С. 81-98.

15. Топоров В. Н. Из «русско-персидского» дивана. Русская сказка *301 А, В и «Повесть о Еруслане Лазаревиче» - «Шах-наме» и авестийский «Зам-язат-яшт» (Этнокультурная и историческая перспектива) // Этноязыковая и этнокультурная история Восточной Европы. - М.: Индрик, 1995. - С. 142-200.

Информация об авторе: Анастасия Сергеевна Льзлова - кандидат филологических наук, научный сотрудник Института языка, литературы и истории Карельского научного центра РАН.

Дата поступления в редакиию: 21.12.2018 Дата публикации: 29.03.2019 
Anastasia S. Lyzlova

(Petrozavodsk, Russian Federation)

alyzlova@illh.ru

\section{Fairy Tales About Three Kingdoms (The Copper, Silver and Gold Ones) in Popular Literature and Russian Folk Tradition}

Acknowledgements. The financial support for the research was carried out from the federal budget for the fulfillment of the state order (project № AAAA-A18-118030190094-6).

Abstract. The article is devoted to the type of a fairy tale plot about three kingdoms (gold, silver and copper) popular in the Russian folk tradition and known in two versions: in one of them the kingdoms are situated under the ground, and in another one they are located on the mountain. The appearance of the second version is related to the very first Russian fairy tale published in 1782 and entitled "The Tale of the Golden Mount, or The Wonderful Adventures of Idan, Prince of the East" which is full of a specific oriental flavor. Later, the text was russianized and published in various cheap popular editions of numerous copies during 150 years (the end of the 18th - the beginning of the 20th century). A book fairy tale still existed in the oral tradition: its versions used to be recorded in various corners of Russia and are included in many collections of Russian folk tales, published in the last quarter of the 19th century, in the first half of the 20 th century and even in the early 21 st century. These texts still conserve certain details (such as the abduction of hero's mother, the presence of four locuses, the enemy's name, the conversion of the kingdoms into an egg etc) associated specifically with popular sources, which are not always easily recognizable because they are being lost or transformed in the course of long life of the oral tradition of the folk tale.

Keywords: Russian folk tales, cheap popular literature (luboc), plot type, version, three kingdoms, gold kingdom, silver kingdom, copper kingdom

\section{References}

1. Azadovskiy M. K. Russian Storytellers. In: Azadovskiy M. K. Stat'i o literature i fol'klore [Azadovsky M. K. Articles About Literature and Folklore]. Moscow, Leningrad, Goslitizdat Publ., 1960, pp. 15-79. (In Russ.)

2. Barag L. G., Novikov N. V. Notes. In: Narodnye russkie skazki A. N. Afanaséva: $\checkmark 3$ tomakh [Russian Folk Tales by A. N. Afanasyev: in 3 Vols]. Moscow, Nauka Publ., 1984, vol. 1, pp. 432-505. (In Russ.)

3. Dobrovol'skaya V. E. Predmetnye realii russkoy volshebnoy skazki [The Subject Realities of the Russian Fairy Tale]. Moscow, the State Republican Centre of Russian Folklore Publ., 2009. 224 p. (In Russ.)

4. Koz'min A. V. The Popularity of Fairytale Plots. In: Problemy strukturnosemanticheskikh ukazateley [The Problems of Structural-Semantic Indexes]. Moscow, the Russian State University for the Humanities Publ., 2006, 
pp. 156-166. (In Russ.)

5. Korepova K. E. Popular Folk Tales About Three Underground Kingdoms and Their Influence on the Oral Tradition. In: Fol'klor narodov RSFSR [Folklore of the Peoples of the RSFSR]. Ufa, Bashkir State University Publ., 1991, pp. 5-12. (In Russ.)

6. Korepova K. E. Russkaya lubochnaya skazka [The Russian Popular Fairy Tale]. Nizhny Novgorod, KiTizdat Publ., 1999. 243 p. (In Russ.)

7. Korepova K. E. At the Origins. In: Lekarstvo ot zadumchivosti. Russkaya skazka v izdaniyakh 80-kh godov 18 veka [The Remedy Against Pensiveness. The Russian Fairy Tale in the Editions of the 1780s]. St. Petersburg, Tropa Troyanova Publ., 2001, pp. 5-16. (In Russ.)

8. Korepova K. E. Russkaya lubochnaya skazka [The Russian Popular Fairy Tale]. Moscow, FORUM Publ., 2012. 464 p. (In Russ.)

9. Lyzlova A. S. Ab Ovo: About Semantics of the Russian Fairy Tale Image. In: Problemy istoricheskoy poetiki [The Problems of Historical Poetics]. Petrozavodsk, 2016, vol. 4, pp. 136-152. Available at: http://poetica.pro/ files/redaktor_pdf/1481891910.pdf (accessed on December 18, 2018). DOI: 10.15393/j9.art.2016.3748 (In Russ.)

10. Propp V. Ya. Istoricheskie korni volshebnoy skazki [Historical Roots of the Magic Fairy Tale]. Moscow, Labirint Publ., 2005. 332 p. (In Russ.)

11. Russkie narodnye kartinki: $v 5$ knigakh [Russian Folk Pictures: in 5 Books]. St. Petersburg, Typography of the Academy of Sciences Publ., 1881, book 1. 509 p. (In Russ.)

12. Russkie narodnye kartinki: $v 2$ tomakh [Russian Folk Pictures: in 2 Vols]. St. Petersburg, Tropa Troyanova Publ., 2002. 342 p. (In Russ.)

13. Savchenko S. V. Russkaya narodnaya skazka: Istoriya sobiraniya i izucheniya [The Russian Folk Tale: the History of Compilation and Study]. Kiev, Typography of the Imperial University of St. Vladimir Publ., 1914. 543 p. (In Russ.)

14. Toporov V. N. To the Question of the Reconstruction of the Myth About the World Egg (Based on Russian Fairy Tales). In: Trudy po znakovym sistemam [Sign Systems Studies]. Tartu, Tartu State University Publ., 1967, issue 3, pp. 81-98. (In Russ.)

15. Toporov V. N. From the "Russian-Persian" Sofa. The Russian Fairy Tale * 301 A, B and "The Tale About Eruslan Lazarevich" - "Shah-name" and Avestan "Zam-yazat-yasht" (Ethno-cultural and Historical Perspectives). In: Etnoyazykovaya i etnokul'turnaya istoriya Vostochnoy Evropy [The Ethnolingual and Ethnocultural History of Eastern Europe]. Moscow, Indrik Publ., 1995, pp. 142-200. (In Russ.)

Information about the author: Lyzlova Anastasia S. - PhD in Philology, researcher of Institute of Linguistics, Literature and History of the Karelian Research Centre of the Russian Academy of Sciences.

Received: December 21, 2018

Date of publication: March 29, 2019 